\title{
First find of biogenic activity in the Palaeoproterozoic of the Singhbhum craton (E India)
}

\author{
A.J. van Loon ${ }^{1}$, R. Mazumder ${ }^{2}$ \\ ${ }^{1}$ Geological Institute, Adam Mickiewicz University, Maków Polnych 16, 61-606 Poznan, Poland; \\ email: tvanloon@amu.edu.pl; tom.van.loon@wxs.nl \\ ${ }^{2}$ School of Biological, Earth and Environmental Sciences, University of New South Wales, Kensington, Sydney, NSW \\ 2052, Australia; e-mail: rajat.mazumder@unsw.edu.au
}

\begin{abstract}
The Palaeoproterozoic succession of the Singhbhum craton in E. India was hitherto considered as almost entirely siliciclastic and partly volcanogenic. Here we describe, from the fine-grained, tidally influenced shale facies of the Palaeoproterozoic Chaibasa Formation (2.1-1.6 Ga), a fine, originally more or less horizontal, wavy to strongly undulating (later locally deformed) lamination. Investigation of these laminae shows that they must be ascribed to the accumulation of fine particles on microbial mats that covered a sandy substrate. The structures must therefore be considered as stromatolites, features that are accepted as proof of the presence of micro-organisms, in this case most probably cyanobacteria. The interpretation of biogenic activity is supported by microscopic analysis. It is the first description of traces left by biogenic activity that took place in the Palaeoproterozoic of the Singhbhum craton.
\end{abstract}

Key words: stromatolites, Palaeoproterozoic, Chaibasa Formation, Singhbhum craton, siliciclastic, shelf

\section{Introduction}

The Palaeoproterozoic of the Singhbhum craton in eastern India is considered as entirely siliciclastic and volcanogenic. Only the uppermost unit, the Chandil Formation contains carbonaceous sediments that probably have a biogenic origin, but no fossils or recognizable traces of biogenic activity have been found thus far. Moreover, the carbonaceous sediments have been dated, on the basis of zircon SHRIMP dates of the associated rhyolite and tuffs in this formation, as around $1600 \mathrm{Ma}$ by Nelson et al. (2007) and more precisely as $1628.5 \pm 4.3$ Ma by Reddy et al. (2009), so that the carbonaceous sediments are at most only marginally Palaeoproterozoic in age. Here we focus on distinct signs of biogenic activity in the Chaibasa Formation (2.1-1.6 Ga) from which thus far only siliciclastic sediments have been described (Bose et al., 1997; Mazumder, 2005; Mazumder et al., 2009). Much attention has been paid to the depositional history of this formation (see the next section), but the genesis of some finely laminated units (Fig. 1) was, however, never investigated in detail. The sedimentary context of these laminated sediments has now been investigated in two sections in a unit in which these laminated sediments dominate, and by microscopic analysis.

The objective of this new analysis was to find out which depositional agent/mechanism was responsible for the formation of these finely laminated units. 


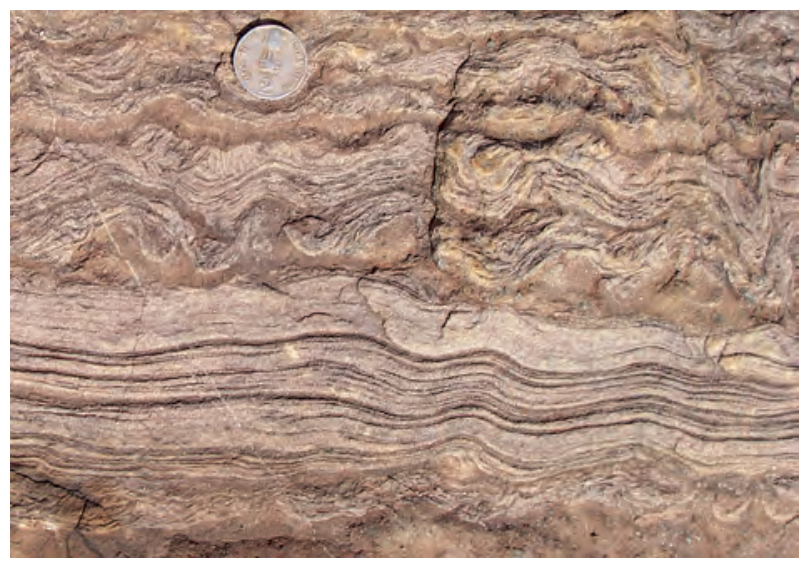

Fig. 1. The finely laminated sediments consisting entirely of small siliciclastic particles.

\subsection{Geographical and geological setting}

The study area is located near Dhalbhumgarh $\left(22^{\circ} 31^{\prime} 39.5724^{\prime \prime} \mathrm{N}, 8^{\circ} 33^{\prime} 39.1968^{\prime \prime}\right.$ E; Fig. 2) and represents the lowermost part of the Chaibasa Formation. The finely laminated sediments under study here occur exclusively in the fine-grained facies, and only locally.

The Chaibasa Formation is $6-8 \mathrm{~km}$ thick and rests partly on an Archaean granitic basement, partly on the terrestrial Dhanjori Formation; it is overlain by the mainly volcaniclastic Dhalbhum Formation (Bose et al., 1997; Mazumder \& Sarkar, 2004; Mazumder, 2005) (Fig. 2). The Chaibasa Formation has not been dated itself, but the underlying Dhanjori mafic volcanics are $2100 \mathrm{Ma}$ (Roy et al., 2002a), whereas the younger Dalma Fm. has been intruded by igneous rocks that have been dated as $1600 \mathrm{Ma}$ (Roy et al., 2002b). The Dalma Formation - and thus also the underlying Chaibasa Formation - must therefore be older (possibly considerably older). Because of the datings of under- and overlying rocks, the Chaibasa Formation is evidently of Palaeoproterozoic age: its age ranges maximally from 2.1 to $1.6 \mathrm{Ga}$, but may also cover only part of this time-span.

The Chaibasa Formation is built of repeated alternations of quartzites (metamorphosed sandstones), heterolithic units (very fine sandstone/shale intercalations) and mica schists (metamorphosed shales with or without fine sandstone/siltstone intercalations) (Bhattacharya, 1991; Bose et al., 1997; Mazumder, 2005).
The small grain size, good sorting, compositional and textural maturity, local occurrence of oppositely directed current ripples, and characteristic rhythmical variations in the thickness of the foresets of cross-stratified beds jointly indicate a tidal origin of the Chaibasa sandstones (Bose et al., 1997; Mazumder, 2004, 2005). The depositional environment of the Chaibasa shale facies is discussed in more detail below.

Post-depositional deformation phases and greenschist to amphibolite facies metamorphism turned the muds into mica schists and the fine sands into quartzitic sandstones (Naha, 1965; Saha, 1994). The schists dominate the fine-grained facies. They are mostly several decimetres thick, whereas the very fine sandstones rarely exceed $4 \mathrm{~cm}$ in thickness, more commonly forming laminae of only a few $\mathrm{mm}$ thick.

\section{Depositional environment of the fine-grained facies of the Chaibasa Fm.}

Apart from the predominant mudstones, the fine-grained shale facies locally contains some thin, very fine-grained sandstones/siltstones. These layers show current ripples and have sharp, often fluted bases (Bose et al., 1997), and they pass upward into draping laminae and then into horizontally laminated sandstones (Mallik et al., 2012, their Fig. 3a). The ripples are strongly asymmetric with a tendency to form ripple-drift cross-lamination. These rippled layers are vertically separated from each other by sheet-like shale layers with gradual lower boundaries but commonly sharp tops (Mallik et al., 2012, their Fig. 3b).

The asymmetric ripples within the sandy layers of the Chaibasa shale record traction currents. The gradual upward transition from draping lamination to horizontal lamination in the fine-grained beds indicates a progressive slowing down of the current, eventually allowing settling of suspension load. Grading within the fine sandstone laminae suggests deposition from suspension (Mazumder et al., 


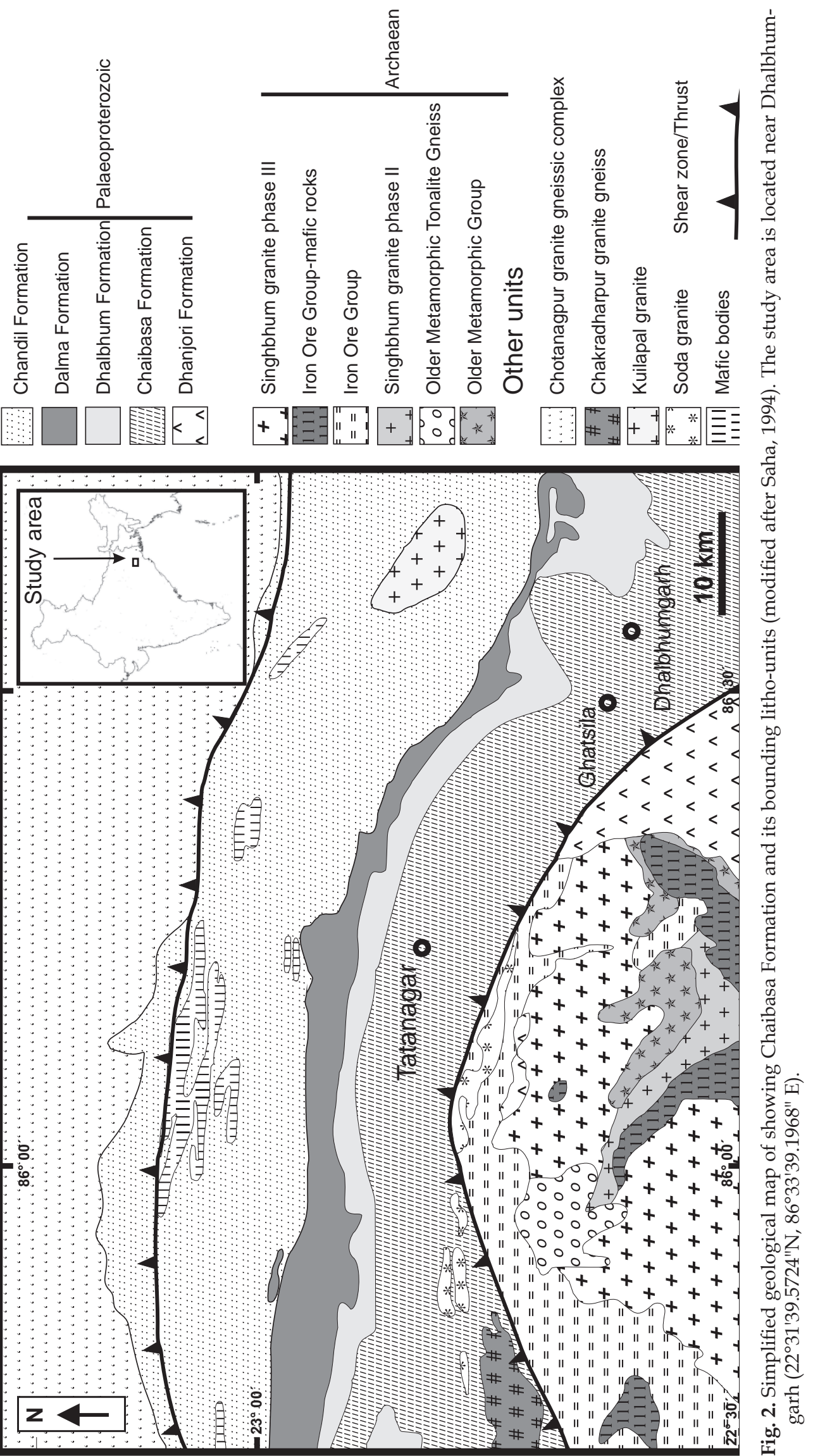


2009; Mallik et al., 2012). The very fine-grained character, without any coarse material, rules out supply by a nearby river, although it cannot be completely excluded that the source material of the sediment was already fine-grained; no such possible parent deposits are known, however. The source of the sediments was thus possibly the more distal shelf. Slump scars and slump folds in the heterolithic facies support this interpretation (Bose et al., 1997; Mazumder, 2005).

The shelf on which the sediments under study were deposited must have been affected by tidal activity, as indicated by numerous mud drapes over sandy ripple sets or ripple trains, as well as by the frequent occurrence of small current ripples in opposite directions (Fig. 3; see also figs $4 \mathrm{a}$ and $4 \mathrm{~b}$ in Mallik et al., 2012). The presence of some channels, up to about a metre deep, with a shape indicating a meandering pattern, fits into a tidally-influenced distal-shelf setting.

\section{The finely-laminated sediments}

The entire fine-grained facies of the Chaibasa Fm. contains laminated sediments, consisting of alternations of fine sandy and muddy horizontal laminae that are commonly less than a millimetre thick; these laminae are usually continuous over long distances (tens of metres or more) and they tend to be associated with small current ripples. We consider this lamination to result from settling in commonly quiet water, with episodic low-energy currents forming small-scale ripples.

There occur, however, also some intervals that are dominated by a less continuous lamination, which shows - although intercalated between units with the continuous horizontal lamination described above - a wavy to strongly undulating character; the units with this diverging type of lamination also have a somewhat more whitish colour than the - more brownish - units with 'normal' horizontal lamination. Both the 'normally' and the 'specially' laminated sediments often show abundant soft-sediment deformations (Fig. 4), but the 'special' laminated units under study here seem more susceptible to such deformation (Fig. 5) than the 'normal' units. The soft-sediment deformation structures have different origins (Mazumder et al., 2009), but many of them have been caused by seismic shocks (a post-depositional tectonic origin can be excluded because both the under- and overlying layers are commonly undeformed). Some of the resulting structures, which were earlier described as "enigmatic" (Van Loon, 2009; his fig. 30B) are currently under study.

In a relatively quiet environment, where fine particles can settle, thin laminae tend to be continuous over large distances, representing alternating phases of settling from suspension and 'events' (such events can, for instance, be slow tidal currents). It is therefore remarkable that the laminae under study are, as a rule, not laterally extensive: although some of them extend laterally over several metres, most of them have a much more restricted extent. Moreover, the laminae often seem to fade out gradually (Fig. 6), which is not a common feature in basins where siliciclastic fine-grained sediments accumulate under predominantly quiet conditions.

\subsection{Sections dominated by fine lamination}

Although the Chaibasa Fm. is several kilometres thick, of which the fine-grained facies constitutes the larger part, no units have been found thus far in which the finely laminated sediments dominate vertically over more than about a metre. Two such sections have been mapped in detail. Both sections represent the same stratigraphic interval, and they are only $11 \mathrm{~m}$ apart. These sections have been selected not only to analyse the sedimentary succession in detail, but also to evaluate the rapid lateral changes in the nature of the sediments.

It turns out that both the mud and the sand laminae can reach different thicknesses from less than $1 \mathrm{~mm}$ to (rarely) about $5 \mathrm{~mm}$. The mud laminae are almost all structureless; some show a vague base-parallel banding. The sand laminae show more variation: the thin (commonly less than a mm thick) laminae do not contain any structures that are visible 


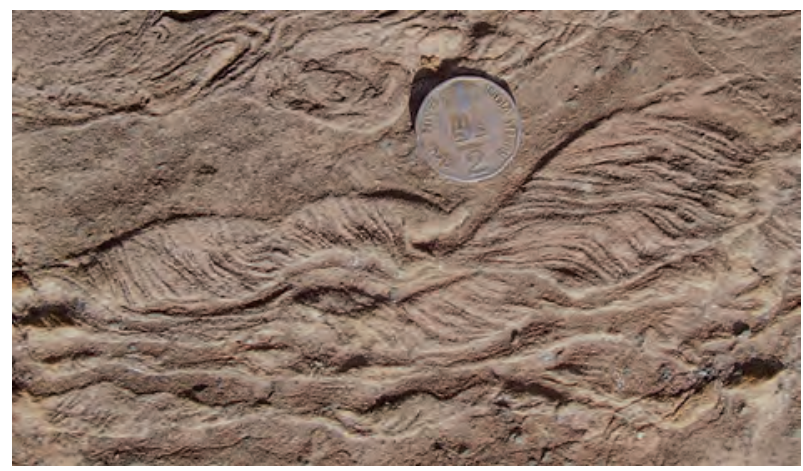

Fig. 3. Deformed small-scale fine sandy current ripples in opposite directions.

with naked eyes, but the thicker laminae show as a rule structures such as current-induced cross-lamination (indicating tidal currents) and micro-loadcasts. Some of these thicker sandy levels show chaotic deformations; such deformations can, however, also affect a set of sandy and muddy laminae.

The two sections have in common that they start with a thick interval (some $75 \mathrm{~cm}$ in section 1 and some $85 \mathrm{~cm}$ in section 2) that shows complex deformations, as visible by differential weathering of some laminae. Then follows a unit (of some $80 \mathrm{~cm}$ in both sections) in which successions of thin laminae alternate with more irregular, commonly thicker, laminae, and the top unit (about 65 and $55 \mathrm{~cm}$, respectively) consists for the great majority of the typical fine laminae that are the subject of the present study. These laminae are overlain by 'normally' laminated fine-grained layers.

In spite of the overall similarity between the two sections, they differ greatly if considered in detail. Specific $\mathrm{cm}$-scale units that build up the three units mentioned above cannot be traced

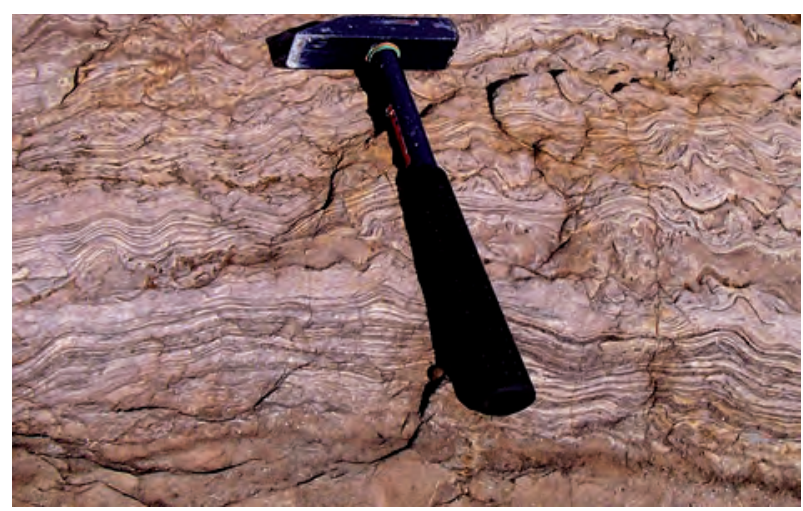

Fig. 5. Seismite consisting of a unit built by 'thin' laminae.

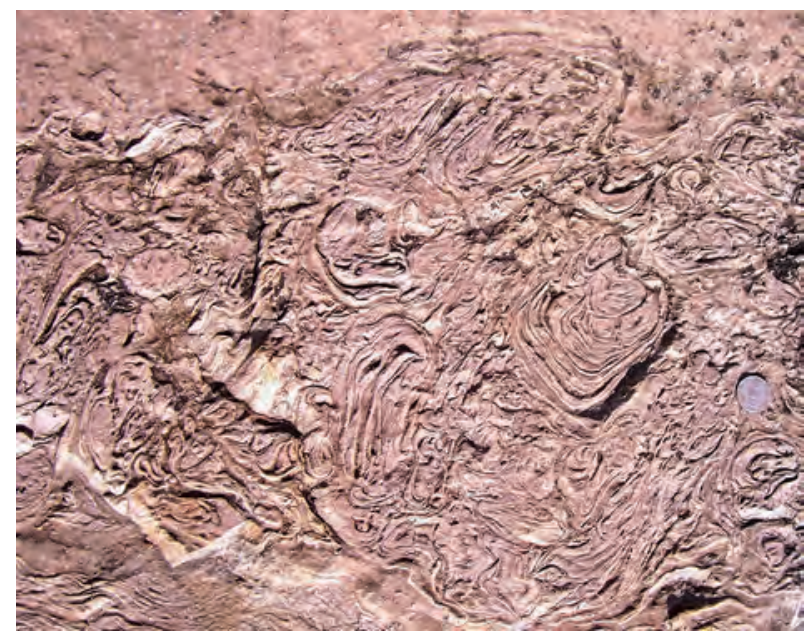

Fig. 4. Layer with chaotic deformation resulting from a series of seismic shocks.

from one section to the other. This is due partly to deformations that have broken up laminae, but this concerns the lowest unit mainly. More common is that the laminae in the top part of both sections laterally fade out (Fig. 6) or stop abruptly.

\subsection{Characteristics and genesis of the 'thin' laminae}

Obviously, the fine lamination of the sediments under study is the most conspicuous feature. This lamination can be deformed by the same post-depositional processes that have deformed other layers, but they are - also in non-deformed layers - more irregular than the 'normal' laminae. Moreover, the irregularities in the lamination are not always consistent with the overall deformations: they look like irregular encrustations of an object that is no

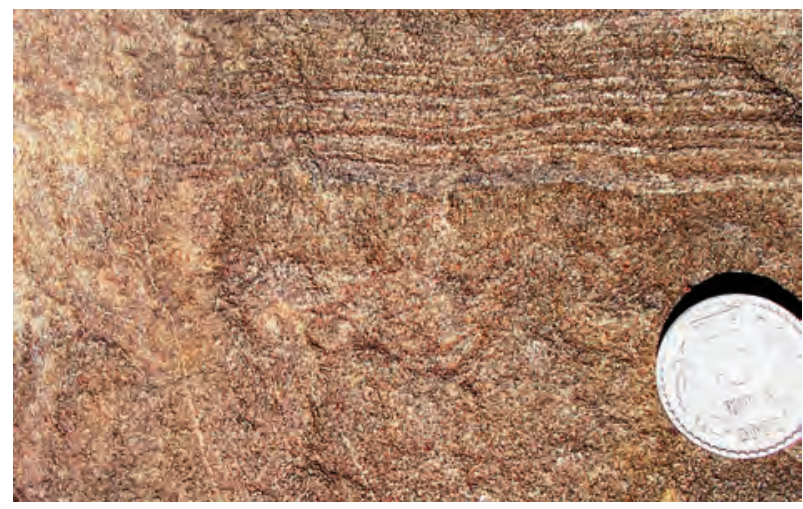

Fig. 6. Laminae gradually fading out laterally. 

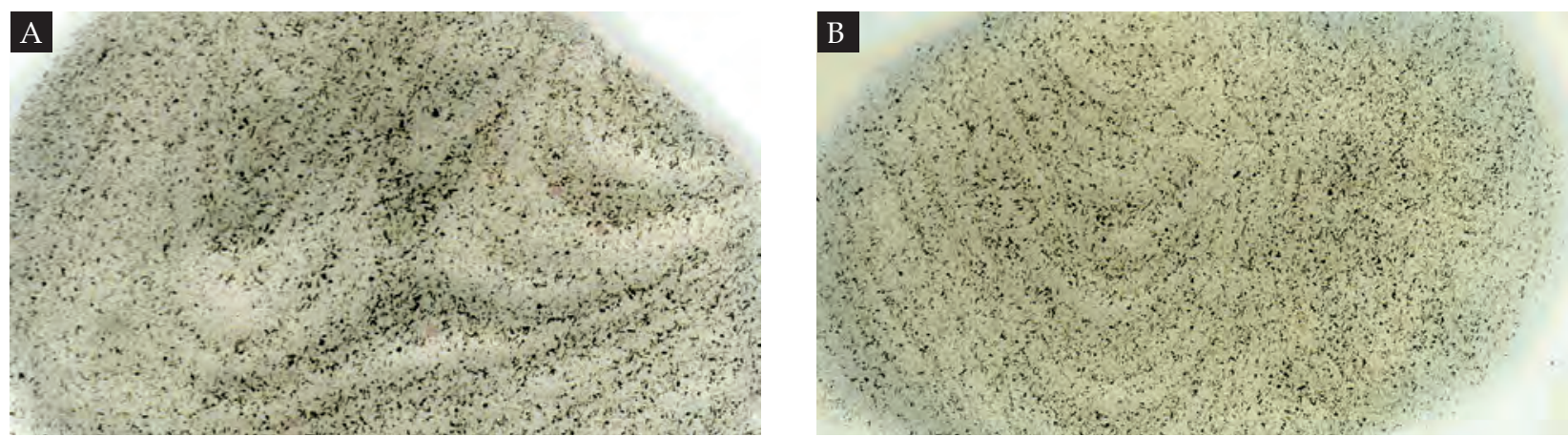

Fig. 7. The fine laminae in thin section (plain light).

A: Horizontal 'fine' laminae with a zone of more or less concentric rings around a non-discernible object. Width of picture approx. $3.5 \mathrm{~cm}$; B: Deformed horizontal 'fine' laminae with strong variations in grain size within individual laminae. Width of picture approx. $3.3 \mathrm{~cm}$.
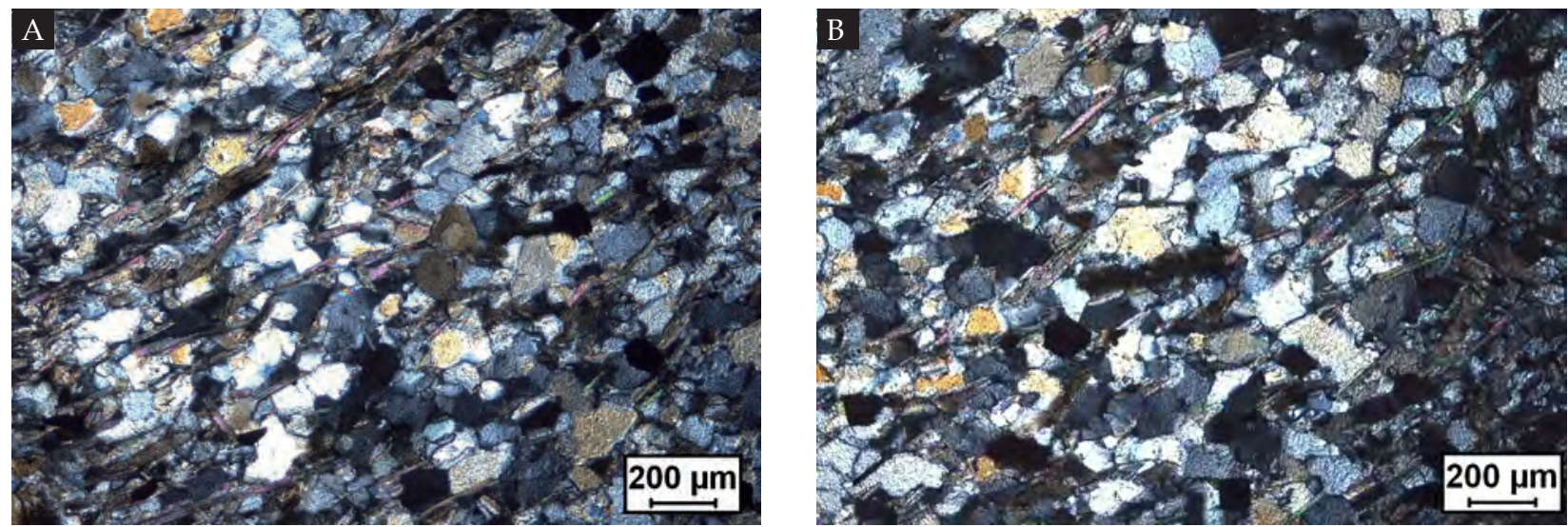

Fig. 8. Microphotos (crossed nicols) of the laminated sediments.

A: Part of a finely laminated succession with relatively much mica. Note also the 'banding' of finer and coarser material; B: Part of a 'normally' laminated succession with relatively little mica

more present. This is well visible when thin sections are microscopically analysed (Fig. 7A). Another difference with the 'normal' laminae is that the fine laminae are, as a rule, fin-

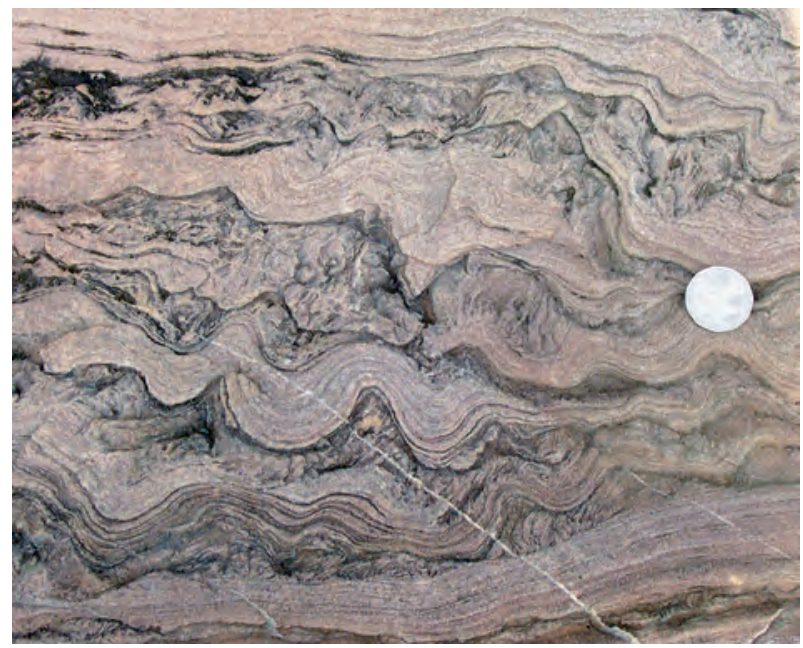

Fig. 9. Typical appearance of the stromatolites. er-grained but with a much wider range in the size of the individual particles, as can also be seen in thin section with a microscope (Fig. 7B). These characteristics are not displayed by the 'normal' laminae.

Microscopic analysis does not add much to the above observations. The finely laminated sediments consist almost entirely of angular to subangular quartz grains and micas. The grains show an orientation that must be ascribed to the metamorphism that the sediments underwent. There is nevertheless also in this respect a small difference between the fine and the normal laminations: the former seem to contain somewhat more micas (Fig. 8A) than the latter (Fig. 8B), which implies that the latter are somewhat better sorted, and that some process led to the 'capture' of the finer-grained micas in the laminae under study. 
The above characteristics, both macroscopic and microscopic, indicate that the fine lamination originated in another way than the normal laminae that settled from suspension in the distal (but still tidally influenced) shallow-marine environment. Particularly the 'encrustations', the individual laminae consisting of both very fine micas and considerably larger quartz particles and the 'capture' of relatively many micas in an otherwise quartz-dominated succession require special conditions. Similar characteristics are known from stromatolites, although these occur much more commonly in a purely calcareous than in a siliciclastic environment. We can explain the various characteristics of these fine laminae satisfactorily only as representing the capture of sedimentary particles of different size and composition on the slimy organic material of organisms that built stromatolites. Such an interpretation was also reached by Nora Noffke when visiting the exposure; she also ascribed the structures to the presence of micro-organisms, probably cyanobacteria (Nora Noffke, Old Dominion University, pers. comm., 2010). Stromatolitic structures in siliciclastic sediments may be rare, but have been described from several other places, also from the Palaeoproterozoic - and even earlier (Noffke, 2010).

\section{Discussion and conclusions}

It is not possible to interpret the 'thin' lamination as the result of settling from suspension. The most convincing evidence against such an interpretation are the gradual lateral fading out and the abrupt lateral ending of these thin laminae, whereas all 'normal' laminae are continuous over large distances, which is only logical under quiet marine conditions.

The Palaeoproterozoic of the Singhbhum craton in E India was considered until now as a siliciclastic/volcanogenic succession from which no traces of biogenic activity were known. The 'thin' lamination in the Chaibasa Formation, which is - according to both its macroscopic and microscopic characteristics due to accumulation of fine silicicastic particles on top of a biofilm (presumably consisting of cyanobacteria), must therefore be considered as the first (and consequently also as the oldest) trace of biogenic activity in the Palaeoproterozoic of this craton. The accumulation of siliciclastics on these biofilms implies that the finely laminated sediments should be considered as stromatolites (Fig. 9). The cyanobacteria must have lived on the bottom of a tidally influenced shelf environment where fine-grained siliciclastic substrata formed apparently a suitable habitat where they could survive under tectonically unstable conditions, considering the frequency of deformation structures in these deposits that indicate seismic shocks (see also Mazumder et al., 2006).

\section{Acknowledgements}

RM is grateful to the University of New South Wales for a postdoctoral research fellowship and to the Indian Statistical Institute for necessary financial support related to the field work. Fieldwork by AJvL for this research project was supported by the Foundation Dr Schürmannfonds, grants no. $57 / 2009$ and $67 / 2010$. The help by Mr Shuvabrata De during the field and laboratory work is greatly appreciated. This is an IGCP-509 contribution.

\section{References}

Bhattacharyya, D.S. \& Bhattacharya, T.K., 1970. Geological and geophysical investigations of a basaltic layer in Archaean terrain of eastern India. Geological Society of America Bulletin 81, 3073-3078.

Bhattacharya, H.N., 1991. A reappraisal of the depositional environment of the Precambrian metasediments around Ghatshila-Galudih, eastern Singhbhum. Journal of the Geological Society of India 37, 47-54.

Bose, P.K., Mazumder, R. \& Sarkar, S., 1997. Tidal sandwaves and related storm deposits in the transgressive Protoproterozoic Chaibasa Formation, India. Precambrian Research 84, 63-81.

Mallik, L., Mazumder, R., Mazumder, B.S., Arima, M. \& Chatterjee, P., 2012. Tidal rhythmite in offshore shale: a case study from Paleoproterozoic Chaibasa shale, eastern India and its implications. Marine and Petroleum Geology 30, 43-49.

Mazumder, R., 2004. Implications of lunar orbital periodicities from Chaibasa tidal rhythmite of late Paleoproterozoic age. Geology 32, 841-844.

Mazumder, R., 2005. Proterozoic sedimentation and volcanism in the Singhbhum crustal province, India and their implications. Sedimentary Geology 176, 167-193. 
Mazumder, R. \& Sarkar, S. 2004. Sedimentation history of the Palaeoproterozoic Dhanjori Formation, Singhbhum, India and its implications. Precambrian Research 130, 267-287.

Mazumder, R., Van Loon, A.J. \& Arima, M., 2006. Soft-sediment deformation structures in the Earth's oldest seismites. Sedimentary Geology 186, 19-26.

Mazumder, R., Rodriguez-Lopez, J.A., Arima, M. \& Van Loon, A.J., 2009. Palaeoproterozoic seismites (finegrained facies of the Chaibasa Fm., E. India) and their soft-sediment deformation structures. [In:] S.M. Reddy, R. Mazumder, D.A. Evans \& A.S. Collins (Eds): Palaeoproterozoic supercontinent and its global evolution. Geological Society of London, Special Publications 323, 301-318.

Naha, K., 1965. Metamorphism in relation to stratigraphy, structure and movements in parts of east Singhbhum, Eastern India. Quaternary Journal of the Geological, Mineralogical, Metallurgical Society of India 37, 41-88.

Nelson, D.R., Bhattacharya, H.N., Misra, S., Dasgupta, N. \& Altermann, W., 2007. New SHRIMP U-Pb zircon dates from the Singhbhum craton, Jharkhand-Orissa region, India. [In:] S. Banerjee (Ed.): Abstracts International Conference on Precambrian Sedimentation \& Tectonics $\mathcal{E}$ 2nd GPSS Meeting, Indian Institute of Technology, Bombay, 2009, 47.

Noffke, N., 2010. Geobiology - Microbial mats from the Archean era to today. Springer-Verlag, Berlin, $194 \mathrm{pp}$.

Reddy, S.M., Clarke, C. \& Mazumder, R., 2009. Temporal constraints on the evolution of the Singhbhum Crus- tal Province from U-Pb SHRIMP data. [In:] D. Saha \& R. Mazumder (Eds.): Paleoproterozoic supercontinents and global evolution. Abstract volume. International Association for Gondwana Research Conference Series 9, 17-18.

Roy, A., Sarkar, A., Jeyakumar, S., Aggrawal, S.K. \& Ebihara, M., 2002a. Sm-Nd age and mantle characteristics of the Dhanjori volcanic rocks, Eastern India. Geochemical Journal 36, 503-518.

Roy, A., Sarkar, A., Jeyakumar, S., Aggrawal, S.K. \& Ebihara, M., 2002b. Mid-Proterozoic plume-related thermal event in Eastern Indian craton: evidence from trace elements, REE geochemistry and Sr-Nd isotope systematics of basic-ultrabasic intrusives from Dalma Volcanic Belt. Gondwana Research 5, 133-146.

Saha, A.K., 1994. Crustal evolution of Singhbhum-North, Orissa, eastern India. Geological Society of India Memoir 27.

Van Loon, A.J., 2009. Soft-sediment deformation structures in siliciclastic sediments: an overview. Geologos $15,3-55$. 